\title{
Job Characteristics and its' Impact on Nurses' Work Motivation at Main Assuit University Hospital
}

\author{
Ebtisam A. Saber ${ }^{1}$, Samah M Abdalla ${ }^{2}$ \& Hala R. Yousef ${ }^{3}$. \\ Assistant lecturer in Nursing Administration Department Faculty of Nursing Assuit University, Egypt. \\ Prof of Nursing Administration Faculty of Nursing Assiut University, Egypt. \\ Prof of Nursing Administration Faculty of Nursing Assiut University, Egypt.
}

\begin{abstract}
Introduction: Years ago there were an idea that pay is the most important cause of work motivation. Later, researchers found that the design and the characteristics of the job greatly affect the employee motivation. Aims: Identify the extent to which the nurse's job have skill variety, task identity, task significance, autonomy and feedback, assess the nurses internal work motivation, and find the effect of job characteristics on nurses internal work motivation. Study design: A descriptive correlational design was used. Setting: The study was conducted at Main Assuit University Hospital. Subject and Method: The subject of the study was all bedside nurses working in the Intensive Care Units at Main Assuit University Hospital (159). A self - administered questionnaire was used to collect data which includes: Personal data sheet, Work Design Questionnaire, and Multimethod Job Design Questionnaire. Results: Autonomy and Feedback correlated positively and significantly with motivation. Conclusion: Activities performed by nurses have high skill variety, task identity, task significance, autonomy and feedback and high internal work motivation, also the most effective core job characteristics on motivation were autonomy and feedback. Recommendations: organizations system should include information about the importance of job characteristics in improving nurses' satisfaction, motivation and quality of care.
\end{abstract}

Keywords: Job Characteristics, Motivation \& Nurses.

\section{Introduction}

Many years ago, Job Characteristics Model (JCM) was one of the most effective models of job design. This model has been used to explain important work outcomes for workers Craig \& Antoinette, (2008) Identify worker-perceived job characteristic deficiencies Leblanc, (2013) Diagnose existing jobs and to evaluate the effects of job changes on employees for outcomes such as motivation, productivity, and satisfaction (Batchelor, et al., 2014).

The core job characteristics are skill variety, task identity, task significance, autonomy, and feedback. Critical psychological states are "experienced meaningfulness of work", "experienced responsibility for outcomes or work," and "knowledge of results." Personal and work outcomes are high internal work motivation, high quality work performance, high satisfaction with work, and low absenteeism and turnover (Shani \& AnandKumar, 2011 \& Batchelor, et al., 2014).

Many studies assume that pay is the most important cause of work motivation. Later, the researchers found that the design and the characteristics of the job greatly affect the employee motivation. Motivators are elements that are intrinsic to the job, such as success, appreciation, interesting work, enlarged responsibilities, development, and growth opportunities. Herzberg's said that motivators are the circumstances that actually inspire employees to work harder (Bauer\& Erdogan, 2012).

An employee should have ability required and along with ability the readiness of that employee to perform any job is also important. To create the readiness of employees and to motivate them, directors should design jobs that motivate and satisfy the employees on work. Recognizing the need for designing the jobs of workers, Hackman \& Oldham (1975) offered job characteristics model (JCM) (Kumar, et al., 2011).

Workforce is important in any organization, they are the cause of the organization success, so it is essential to promote a stimulating work environment, which promotes happiness, motivates and empowers employees, lowers turnover and absentee rates. Encouraging a work environment that raises personal and professional growth helps to increase harmony and inspiration on all levels, so the sound effects are touched business wide. Frequent training and support develops an employee that is skilled, dependable, competitive, effective and proficient (Dobre, 2013).

\section{Significance of the study}

Yet, little is known about effects of job characteristics on employee personal and work outcomes. Unfortunately, there is a lack of researches related to work design generally. However poor or unsuccessful design of a job will lead to lower productivity, employee turnover, absenteeism, complaints, unionization, and resignations. For these reasons the 
researcher conducts this study in an attempt to assess job characteristics and its impact on motivation among intensive care units nurses at main Assuit University Hospital.

\section{Aims of the study}

The present study aims to

a- Identify the extent to which the nurse's jobs have skill variety, task identity, task significance, autonomy and feedback.

b- Assess the nurses internal work motivation

c- Find the relationship between job characteristics and nurses internal work motivation.

\section{Research Hypotheses}

- There is a positive effect of job characteristics on nurses internal work motivation.

\section{Subject \& Method}

\section{Technical design}

Included the research design, setting, subject, and data collection tools.

\section{Research design}

The present study was done using a descriptive correlational research design.

\section{Study setting}

The present study was conducted in five intensive care units at the Main Assuit University Hospital.

\section{Study subject}

A convenience sample which involved all bedside nurses working in the I.C.Us at the Main Assuit University Hospital with total number (159) nurses, which categorized as follows (42) in General intensive care unit,(42)in Trauma intensive care unit,(20)in Post operative intensive care unit,(41)in Chest intensive care unit and (14)in Medical intensive care unit.

\section{Study tools}

Data of this study was collected with the following tools:

\section{Personal characteristics data sheet}

It was designed to collect data about nurses as; age, educational qualification, years of experience and name of unit.

\section{The Work Design Questionnaire (WDQ)}

It is a self-administered questionnaire that was established by Morgeson \&Humphrey, (2006) and translated by the researcher. It was used to determine the five core job characteristics for nurses working at ICUs, which including 23 items: skill variety (3 items), task identity ( 3 items), task significance (3 items), autonomy (9 items), and feedback (4 items). The nurse's response was rated on a 3-point Likert scale ranging from little scored (1), moderate scored (2) and much scored (3).

\section{Scoring system}

The subject response to each of the 23 items was calculated giving the total core job characteristics score. Score 23 indicated little core job characteristics, score from 24 to 46 indicated moderate core job characteristics and score from 47 to 69 indicated high core job characteristics.

\section{III.Multimethod Job Design Questionnaire (MJDQ):}

It is a self-administered tool developed by Campion, (1988) and translated by the researcher. It included (17) items that were used to measure internal work motivation.

\section{Scoring system}

Regarding to the nurses internal work motivation, the response to each of the 17 items was calculated to give total internal work motivation score. Score 17 indicated that they had little internal work motivation, score from 18 to 34 indicated that they had moderate internal work motivation and score from 35 to 51 indicated that they had high internal work motivation.

\section{Administrative design}

An official approval had been attained to collect necessary data from director of the Main Assiut University Hospital, heads and head nurses of I.C.Us at Main Assiut University Hospital.

\section{Operational design}

A) Preparatory phase.

- This phase took about four months from July to October 2016 to review the literatures regarding the topic of the study and to translate the study tools.

- The study tools were translated into Arabic using the translate-re-translate process. Its' validity was measured by five experts in Nursing Administration reviewed the study tools (Three Professors and one Assistant Professor of Nursing Administration, and one Professor of Community Nursing at Assiut University), and the required modifications were done before the actual data gathering to make it more clear to the participants of the study.

\section{B) Ethical consideration}

- The study proposal approved from the Ethical Committee in Faculty of Nursing - Assiut University.

- The study subject has ethical right to participate, withdraw or refuse participation in the study.

- Oral agreement was obtained from nurses who participated in the study at I.C.Us.

C) Pilot Study.

- A pilot study was done on $10 \%$ of the study participants (20 nurses) to test time estimation and applicability of the questionnaires. It took about two weeks of November 2016. Participants included in the pilot study were included in the study subject because there are no modifications needed. 
- Data collected from pilot study were analyzed and computerized for the reliability of study tool using Cronbach's Alpha coefficient statistical method. It clarified that $\boldsymbol{\alpha}$-coefficient for core job characteristics was $0.82 \%$, internal work motivation $0.87 \%$, and the overall of the total questionnaire had an internal consistency of $\boldsymbol{\alpha}$-coefficient $=\mathbf{0 . 9 4 \%}$.

\section{D) Field work:}

- The researcher collected data through personal interview of each nurse to explain the purpose of the study. After obtaining oral consent from the nurses participated in the study, the study tools (questionnaires) was administered to the participants to fill it and the researcher responded on all the questions of the nurses about the questionnaire, each participant took about (30) minutes to fill the questionnaires, duration of this phase took about 3 months from November 2016 to January 2017.

\section{4-Statistical design}

Collected data were verified prior to computerized data entry and analysis by using statistical software package for social sciences (SPSS) version 20. Data were presented as number and percentages, mean and standard deviations were calculated. Spearman was used. Statistical significant was considered at Pvalue $\leq 0.05$

\section{Results}

Table (1): Personal characteristics of studied nurses $(\mathrm{N}=159)$.

\begin{tabular}{|c|c|c|}
\hline Personal characteristics & No. $(n=159)$ & Percent \% \\
\hline \multicolumn{3}{|l|}{ Age: (years) } \\
\hline $19-22$ & 51 & 32.1 \\
\hline $23-26$ & 56 & 35.2 \\
\hline$>26$ & 52 & 32.7 \\
\hline Mean \pm SD (Range) & \multicolumn{2}{|c|}{$25.69 \pm 4.76(19.0-42.0)$} \\
\hline \multicolumn{3}{|l|}{ Department: } \\
\hline Medical ICU & 14 & 8.8 \\
\hline Post operative ICU & 20 & 12.6 \\
\hline Chest ICU & 41 & 25.8 \\
\hline General ICU & 42 & 26.4 \\
\hline Trauma ICU & 42 & 26.4 \\
\hline \multicolumn{3}{|l|}{ Years of experience: } \\
\hline$<2$ & 61 & 38.4 \\
\hline $2-5$ & 36 & 22.6 \\
\hline$>5$ & 62 & 39.0 \\
\hline Mean \pm SD (Range) & \multicolumn{2}{|c|}{$5.61 \pm 5.77$ (1 month - 25 years $)$} \\
\hline \multicolumn{3}{|l|}{ Educational qualification: } \\
\hline Secondary School of Nursing & 78 & 49.1 \\
\hline Technical Health Institute & 22 & 13.8 \\
\hline Technical Institute of Nursing & 43 & 27.0 \\
\hline Bachelor degree of Nursing Science & 16 & 10.1 \\
\hline
\end{tabular}

Table (2): Core job characteristics as reported by studied nurses $(\mathrm{N}=159)$.

\begin{tabular}{|c|c|c|c|c|c|c|}
\hline \multirow{2}{*}{ Core job characteristics } & \multicolumn{2}{|c|}{ Much } & \multicolumn{2}{|c|}{ Moderate } & \multicolumn{2}{|c|}{ Little } \\
\hline & No. & $\%$ & No. & $\%$ & No. & $\%$ \\
\hline \multicolumn{7}{|l|}{ Skill Variety: } \\
\hline 1. The job needs a variety of abilities. & 132 & 83.0 & 26 & 16.4 & 1 & 0.6 \\
\hline $\begin{array}{l}\text { 2. The job needs me to apply a variation of different skills to } \\
\text { complete the work. }\end{array}$ & 124 & 78.0 & 35 & 22.0 & 0 & 0.0 \\
\hline $\begin{array}{l}\text { 3. The job necessitates me to practice a number of complex or } \\
\text { high-level skills. }\end{array}$ & 60 & 37.7 & 84 & 52.8 & 15 & 9.4 \\
\hline Mean \pm SD (Range) & \multicolumn{6}{|c|}{$7.89 \pm 0.99(5.0-9.0)$} \\
\hline Maximum score & \multicolumn{6}{|c|}{9} \\
\hline Task Identity: & & & & & & \\
\hline
\end{tabular}




\begin{tabular}{|c|c|c|c|c|c|c|}
\hline \multirow{2}{*}{ Core job characteristics } & \multicolumn{2}{|c|}{ Much } & \multicolumn{2}{|c|}{ Moderate } & \multicolumn{2}{|c|}{ Little } \\
\hline & No. & $\%$ & No. & $\%$ & No. & $\%$ \\
\hline $\begin{array}{l}\text { 4. The job includes finishing a part of work that has a recognizable } \\
\text { start and end. }\end{array}$ & 102 & 64.2 & 55 & 34.6 & 2 & 1.3 \\
\hline $\begin{array}{l}\text { 5. The job is organized so that I can do a complete portion of work } \\
\text { from start to end. }\end{array}$ & 106 & 66.7 & 46 & 28.9 & 7 & 4.4 \\
\hline 6. The job lets me to complete work I start. & 82 & 51.6 & 66 & 41.5 & 11 & 6.9 \\
\hline Mean \pm SD (Range) & \multicolumn{6}{|c|}{$7.70 \pm 1.15(4.0-9.0)$} \\
\hline Maximum score & \multicolumn{6}{|c|}{9} \\
\hline \multicolumn{7}{|l|}{ Task Significance: } \\
\hline $\begin{array}{l}\text { 7. The outcomes of my work significantly affect the lives of other } \\
\text { individuals. }\end{array}$ & 129 & 81.1 & 27 & 17.0 & 3 & 1.9 \\
\hline $\begin{array}{l}\text { 8. The job itself is very significant and essential in the broader } \\
\text { structure of things. }\end{array}$ & 104 & 65.4 & 50 & 31.4 & 5 & 3.1 \\
\hline 9. The job has a great impression on people outside the hospital. & 66 & 41.5 & 77 & 48.4 & 16 & 10.1 \\
\hline $\begin{array}{l}\text { 10. The work done on the job has a considerable impact on } \\
\text { individuals outside the organization. }\end{array}$ & 67 & 42.1 & 79 & 49.7 & 13 & 8.2 \\
\hline Mean \pm SD (Range) & \multicolumn{6}{|c|}{$\frac{1}{10.07 \pm 1.46(6.0-12.0)}$} \\
\hline Maximum score & \multicolumn{6}{|c|}{12} \\
\hline \multicolumn{7}{|l|}{ Autonomy } \\
\hline $\begin{array}{l}\text { 1.The job lets me to make my own judgments about how to timetable } \\
\text { my work. }\end{array}$ & 33 & 20.8 & 72 & 45.3 & 54 & 34.0 \\
\hline $\begin{array}{l}\text { 2. The job lets me to decide on the direction in which things are } \\
\text { accomplished on the job. }\end{array}$ & 59 & 37.1 & 72 & 45.3 & 28 & 17.6 \\
\hline 3. $\quad$ The job lets me to design how I do my work. & 67 & 42.1 & 71 & 44.7 & 21 & 13.2 \\
\hline $\begin{array}{l}\text { 4. The job provides me a chance to use my own inventiveness or } \\
\text { decision in accomplishing the work. }\end{array}$ & 36 & 22.6 & 96 & 60.4 & 27 & 17.0 \\
\hline 5. $\quad$ The job lets me make a lot of decisions by myself. & 41 & 25.8 & 74 & 46.5 & 44 & 27.7 \\
\hline $\begin{array}{l}\text { The job offers me with major independence in decision } \\
\text { making. }\end{array}$ & 36 & 22.6 & 74 & 46.5 & 49 & 30.8 \\
\hline $\begin{array}{l}\text { 7. The job lets me make decisions about what techniques I use to } \\
\text { complete my work. }\end{array}$ & 37 & 23.3 & 83 & 52.2 & 39 & 24.5 \\
\hline $\begin{array}{l}\text { 8. The job provides me with great opportunity for independence } \\
\text { in how I do the work. }\end{array}$ & 68 & 42.8 & 67 & 42.1 & 24 & 15.1 \\
\hline $\begin{array}{l}\text { 9. The job gives me the opportunity to independently decide how } \\
\text { to do my work }\end{array}$ & 62 & 39.0 & 79 & 49.7 & 18 & 11.3 \\
\hline Mean \pm SD (Range) & \multicolumn{6}{|c|}{$18.85 \pm 4.05(9.0-26.0)$} \\
\hline Maximum score & \multicolumn{6}{|c|}{27} \\
\hline \multicolumn{7}{|l|}{ Feedback: } \\
\hline $\begin{array}{l}\text { 10. The work activities themselves deliver direct and clear data } \\
\text { about the effectiveness (e.g., quality and quantity) of my job } \\
\text { performance. }\end{array}$ & 58 & 36.5 & 91 & 57.2 & 10 & 6.3 \\
\hline 11. The job itself offers feedback on my performance. & 64 & 40.3 & 73 & 45.9 & 22 & 13.8 \\
\hline $\begin{array}{l}\text { 12. I obtain excessive information from my director and coworkers } \\
\text { about my job performance. }\end{array}$ & 66 & 41.5 & 76 & 47.8 & 17 & 10.7 \\
\hline $\begin{array}{l}\text { 13. Other people in the hospital, such as administrators and } \\
\text { coworkers, provide information about the effectiveness of my } \\
\text { job performance. }\end{array}$ & 54 & 34.0 & 78 & 49.1 & 27 & $\mathbf{1 7 . 0}$ \\
\hline Mean \pm SD (Range) & \multicolumn{6}{|c|}{$9.04 \pm 1.83(4.0-12.0)$} \\
\hline Maximum score & \multicolumn{6}{|c|}{12} \\
\hline Mean \pm SD (Range) for total job characteristics & \multicolumn{6}{|c|}{$53.55 \pm 6.25$} \\
\hline
\end{tabular}


Table (3): Internal work motivation as reported by studied nurses ( $\mathrm{N}=159)$.

\begin{tabular}{|c|c|c|c|c|c|c|}
\hline \multirow{2}{*}{ Internal work motivation } & \multicolumn{2}{|c|}{ Agree } & \multicolumn{2}{|c|}{ Neutral } & \multicolumn{2}{|c|}{ Disagree } \\
\hline & No. & $\%$ & No. & $\%$ & No. & $\%$ \\
\hline $\begin{array}{l}\text { 1. The job provides freedom, independence, or discretion } \\
\text { in work planning, arrangement, techniques, procedures, } \\
\text { quality control, or other decision making. }\end{array}$ & 34 & 21.4 & 78 & 49.1 & 47 & 29.6 \\
\hline $\begin{array}{l}\text { 2. My work offers me with direct feedback about the } \\
\text { effectiveness of my performance. }\end{array}$ & 52 & 32.7 & 92 & 57.9 & 15 & 9.4 \\
\hline $\begin{array}{l}\text { 3. My directors and colleagues give me feedback about } \\
\text { the quality and quantity of my job performance. }\end{array}$ & 69 & 43.4 & 69 & 43.4 & 21 & 13.2 \\
\hline $\begin{array}{l}\text { 4. My job offers the chance for social contact such as } \\
\text { team work or coworker assistance. }\end{array}$ & 103 & 64.8 & 48 & 30.2 & 8 & 5.0 \\
\hline $\begin{array}{l}\text { 5. The job duties, requirements, and goals are clear and } \\
\text { specific. }\end{array}$ & 94 & 59.1 & 55 & 34.6 & 10 & 6.3 \\
\hline 6. I have a variety of duties, tasks, and activities on my job. & 120 & 75.5 & 39 & 24.5 & 0 & .0 \\
\hline $\begin{array}{l}\text { 7. The job needs completion of a total and identifiable } \\
\text { portion of work. }\end{array}$ & 118 & 74.2 & 38 & 23.9 & 3 & 1.9 \\
\hline 8. My job needs a high level of awareness and skills. & 116 & 73.0 & 41 & 25.8 & 2 & 1.3 \\
\hline 9. My job requires a variety of knowledge and abilities. & 126 & 79.2 & 31 & 19.5 & 2 & 1.3 \\
\hline $\begin{array}{l}\text { 10. My job is significant and important compared with } \\
\text { other jobs at the University. }\end{array}$ & 105 & 66.0 & 42 & 26.4 & 12 & 7.5 \\
\hline $\begin{array}{l}\text { 11. My job provides the opportunity for learning and } \\
\text { growth in competence and proficiency. }\end{array}$ & 95 & 59.7 & 58 & 36.5 & 6 & 3.8 \\
\hline $\begin{array}{l}\text { 12. My job provides opportunities for advancement to } \\
\text { higher level jobs. }\end{array}$ & 48 & 30.2 & 58 & 36.5 & 53 & 33.3 \\
\hline $\begin{array}{l}\text { 13. My job gives me a feeling of achievement and } \\
\text { accomplishment. }\end{array}$ & 75 & 47.2 & 64 & 40.3 & 20 & 12.6 \\
\hline $\begin{array}{l}\text { 14. My job gives me the opportunity to participate in } \\
\text { decisions that affect my job. }\end{array}$ & 50 & 31.4 & 88 & 55.3 & 21 & 13.2 \\
\hline $\begin{array}{l}\text { 15. My job offers adequate pay compared with the job } \\
\text { requirements and with pay in similar jobs. }\end{array}$ & 19 & 11.9 & 34 & 21.4 & 106 & 66.7 \\
\hline $\begin{array}{l}\text { 16. The job gives me acknowledgment and appreciation } \\
\text { from others. }\end{array}$ & 37 & 23.3 & 53 & 33.3 & 69 & 43.4 \\
\hline $\begin{array}{l}\text { 17. My job provides me with job security when I work } \\
\text { effectively. }\end{array}$ & 60 & 37.7 & 62 & 39.0 & 37 & 23.3 \\
\hline Mean \pm SD (Range) & & & $=5$ & 27.0 & & \\
\hline Maximum score & & & & & & \\
\hline
\end{tabular}

Table (4): Correlation of job characteristics and internal work motivation of the studied nurses $(\mathrm{N}=159)$.

\begin{tabular}{|l|c|c|}
\hline \multicolumn{1}{|c|}{ Core job characteristics } & & Internal work motivation \\
\hline \multirow{2}{*}{ Skill Variety } & r-value & 0.090 \\
\cline { 2 - 3 } & P-value & 0.259 \\
\hline \multirow{2}{*}{ Task Identity } & r-value & -0.011 \\
\cline { 2 - 3 } & P-value & 0.886 \\
\hline \multirow{2}{*}{ Autonomy } & r-value & 0.137 \\
\cline { 2 - 3 } & P-value & 0.085 \\
\hline \multirow{2}{*}{ Feedback } & r-value & $\mathbf{0 . 3 3 9}$ \\
\cline { 2 - 3 } & P-value & $\mathbf{0 . 0 0 0 * *}$ \\
\hline
\end{tabular}

(**) High statistically significant at $p<0.01$

(*)Statistical significant difference $(P<0.05)$ 
Table (5): Correlation between nurses' age, years of experience and job characteristics and internal work motivation for the studied $(\mathrm{N}=159)$.

\begin{tabular}{|l|c|c|c|c|}
\hline \multirow{2}{*}{\multicolumn{1}{|c|}{ Variables }} & \multicolumn{2}{c|}{ Age (years) } & \multicolumn{2}{c|}{ Years of experience } \\
\cline { 2 - 5 } & r-value & P-value & r-value & P-value \\
\hline Skill variety & $\mathbf{0 . 2 3 6}$ & $\mathbf{0 . 0 0 3} * *$ & $\mathbf{0 . 2 0 9}$ & $\mathbf{0 . 0 0 8} * *$ \\
\hline Task identity & $\mathbf{0 . 1 7 4}$ & $\mathbf{0 . 0 2 9} *$ & $\mathbf{0 . 2 4 9}$ & $\mathbf{0 . 0 0 2} * *$ \\
\hline Task significance & 0.109 & 0.170 & 0.066 & 0.411 \\
\hline Autonomy & 0.068 & 0.398 & 0.138 & 0.083 \\
\hline Feedback & 0.066 & 0.411 & 0.047 & 0.559 \\
\hline Internal work motivation & 0.003 & 0.970 & 0.006 & 0.943 \\
\hline
\end{tabular}

(**) High statistically significant at $p<0.01$

(*)Statistical significant difference $(P<0.05)$

Table (6): Job characteristics and internal work motivation as reported by ICUs studied nurses (N=159).

\begin{tabular}{|l|c|c|c|c|c|c|}
\hline \multirow{2}{*}{\begin{tabular}{c}
\multirow{2}{*}{$\begin{array}{c}\text { Job } \\
\text { characteristics }\end{array}$} \\
\cline { 2 - 7 }
\end{tabular}} & Medical & Trauma & Post-operative & Chest & General & \multirow{2}{*}{ P-value } \\
\cline { 2 - 7 } & Mean \pm SD & Mean \pm SD & Mean \pm SD & Mean \pm SD & Mean \pm SD & \\
\hline Skill variety & $8.00 \pm 0.68$ & $8.07 \pm 1.07$ & $8.35 \pm 0.93$ & $7.66 \pm 1.04$ & $7.67 \pm 0.87$ & $\mathbf{0 . 0 0 6} * *$ \\
\hline Task identity & $8.21 \pm 1.05$ & $8.05 \pm 1.06$ & $8.00 \pm 1.08$ & $7.20 \pm 1.10$ & $7.52 \pm 1.15$ & $\mathbf{0 . 0 0 1} * *$ \\
\hline Task significance & $10.29 \pm 0.61$ & $9.90 \pm 1.25$ & $10.50 \pm 1.05$ & $10.20 \pm 1.60$ & $9.83 \pm 1.82$ & 0.386 \\
\hline Autonomy & $19.50 \pm 2.95$ & $18.86 \pm 4.15$ & $19.60 \pm 4.54$ & $19.05 \pm 3.61$ & $18.07 \pm 4.47$ & 0.660 \\
\hline Feedback & $9.14 \pm 1.10$ & $9.24 \pm 2.02$ & $9.55 \pm 2.04$ & $9.17 \pm 1.77$ & $8.45 \pm 1.68$ & 0.168 \\
\hline $\begin{array}{l}\text { Internal work } \\
\text { motivation }\end{array}$ & $39.00 \pm 6.29$ & $40.19 \pm 4.78$ & $42.50 \pm 4.64$ & $38.93 \pm 5.63$ & $38.45 \pm 4.68$ & $\mathbf{0 . 0 3 8}$ \\
\hline
\end{tabular}

(**) High statistically significant at $p<0.01$

$(*)$ Statistical significant difference $(P<0.05)$

Table (1): Explained Personal characteristics of studied nurses, which displayed that nearly to half of them were graduated from Secondary School of Nursing $(49.1 \%)$. More than one- third of them their experience exceeded 5 years and their age ranged from 23 to 26 years old (39\% and 35.2\%) respectively. More than one quarter of them were working at general ICU and trauma ICU $(26.4 \%$ and $26.4 \%$ ) respectively.

Table (2): Showed the core job characteristics as described by the studied nurses.

Concerning skill variety, the majority of the studied nurses $(83.0 \%)$ stated that their jobs require a variety of abilities. Meanwhile, only (9.4\%) considering that their job needs a little number of hard or high-level skills.

Concerning task identity, a high percent of the studied nurses $(66.7 \%)$ reported that their jobs are prepared to do a complete portion of work from start to end. Alternatively, only (6.9\%) reported the job giving them little opportunity to complete work they start.

As for task significance, the majority of the studied nurses $(81.1 \%)$ reported that the outcome of their work significantly affecting the lives of other individuals. While, only $(10.1 \%)$ mentioned that the job has a little impression on people outside the hospital.

Regarding autonomy, less than half of the studied nurses $(42.8 \%)$ stated that their jobs give them great opportunity for independence in how they do the work. Meanwhile, about one third of them (34.0\%) reported that the job giving them little chance to make their own decisions about how to timetable their work.

As regards to feedback, less than half of the studied nurses $(41.5 \%)$ stated that they take enough information from their director and colleagues about their job performance. Alternatively, only $(17.0 \%)$ reported that other individuals in the hospital, such as directors and colleagues, give little information about the effectiveness of their job performance. The mean score for all core job characteristics was high compared with the maximum score.

Table (3): Illustrated internal work motivation as stated by studied nurses. It showed that high percent of them agreed that their job requires a variety of knowledge and abilities and that they have a variety of duties, tasks, and activities on their job (79.2 and $75.5 \%)$ respectively. Also, high percent of them $(66.7 \%)$ disagreed that their job offers adequate pay as compared with the job requirements and with pay in similar jobs. The mean score for internal work 
motivation was high compared with the maximum score.

The correlation of job characteristics and internal work motivation of the studied nurses showed in Table (4): It revealed that Autonomy and Feedback had significant positive correlation with internal work motivation $(0.000 * *$ and $0.000 * *)$ respectively. However Task Identity had negative but not significant correlation with internal work motivation.

Table (5): Revealed that there were significant positive correlations between age, skill variety, task identity $(0.003 * *, 0.029 *)$ respectively. Also years of experience had significant positive correlation with skill variety, task identity $(0.008 * *, 0.002 * *)$ respectively.

As presented in Table (6): there were statistically significant differences among means of the skill variety, and internal work motivation according to the unit. Post operative (ICU) had the highest mean score $(8.35 \pm 0.93$, and $42.50 \pm 4.64)$ respectively. Also there were statistically significant differences among means of task identity. Medical (ICU) had the highest mean score $(8.21 \pm 1.05)$.

\section{Discussion}

The job characteristics were designed to identify worker perception about job characteristic deficiencies (Michailidis \& Dracou, 2011). This study was done with the aim of identifying the extent to which the nurse's jobs have skill variety, task identity, task significance, autonomy and feedback, assess the nurses internal work motivation, and identifying the effect of job characteristics on nurses internal work motivation.

The findings of the present study showed that, about two thirds of the studied subject had less than 5 years of experience and their age ranged from 19 to 26 years old, this might be because of the system followed by Assuit University Hospital as they transfer old age nurses every five years from intensive care units to general units, and below half of them were graduated from secondary school of nursing Table (1).

Table (2): The present study found high mean scores of the entire core job characteristics for the studied subject. It may be because of the dynamic working environment in intensive care units which require the nurse to have high skill variety, task identity, task significance, autonomy and feedback. This finding was consistent with the result of Alini, et al., (2014) in his study which indicated that all job characteristics dimensions had high mean score. This contradicted with the study results of Gabr\& Mohamed, (2012) who found that nurses had moderate or low mean score in perceiving their job characteristics.
As regards to personal and work outcomes showed in Table (3): the findings of the present study revealed that the study subject was highly motivated this may be due to working in the ICUs was not boring and requires a variety of activities, skills, and knowledge. Although most of them viewed that their job do not offers adequate pay compared with the job requirements and with pay in similar jobs. These findings could be due to the payment system at the university hospital which provides nurses with a small salary compared with nurses working in Ministry of Health and Population Hospitals. This was supported by the study result of Gabr \& Mohamed, (2012) who reported that nurses were unsatisfied with pay. Although the results of the present study contradicted with Mohamed, (2004) study which revealed high perception scores for job satisfaction with pay for ICU nurses because of the payment system which provide more incentives for the ICU nurses who are utilizing the case method of assignment due to their workload.

The present study revealed that autonomy and feedback are the core job characteristics that had significant positive correlation with motivation Table (4). This confirmed the study of Behson, et al., (2000) who had found that autonomy is the core job characteristics with the strongest relationships with motivation. In contrast with the study done by Abu Elanain, (2008) who found that skill variety and task significance affect work motivation also he had found that autonomy was not a valid predictor of variation in motivation. In this respect the study of Hadi \& Adil, (2010) \& Nadeem, et al., (2012) indicated that the overall job characteristics were positively related to work motivation. Also Iffat, et al., (2015) recognized that the five job characteristics were significant for motivating employees in the organization.

The present study indicated that mean job characteristic perceptions according to age and years of experience had significant difference for skill variety and task identity Table (5), this is because when age increased and the nurse had more years of experience the quality of performance increased and the nurse had to be responsible for the more complex tasks in the ICUs. Mohamed, (2004) indicated significant positive relationship between the overall perceptions of professional nurses about the core job characteristics and their age and years of experience In contrast, these relationships were negative for the technical nurses who were working in the ICUs. Bahrami, et al., (2013) found that no significant difference was noticed between the mean of job characteristic perceptions according to age, while a significant difference was noticed between the job 
characteristic perceptions according to the years of experience.

The present study showed that there were statistically significant differences among means of the skill variety, task identity, and motivation in accordance to the unit Table (6). This was consistent with Bahrami, et al., (2013) study which indicated that a significant difference was noticed between the job characteristic and internal work motivation perceptions according to the unit of service.

\section{Conclusions}

In the light of the present study findings, the following conclusions can be drawn as:

- Below half of the intensive care units nurses were graduated from secondary school of nursing, had more than 5 years of experience and their age ranged from 23 to 26 years old.

- The intensive care units nurse's jobs have high skill variety, task identity, task significance, autonomy and feedback.

- (I.C.Us) nurses have high positive work outcome in term of internal work motivation.

- Autonomy and feedback has a great effect on internal work motivation .

- Skill variety and task identity affected positively by nurse's age and years of experience.

- There were statistically significant differences among means of the skill variety, task identity and motivation according to the units of studied nurses.

\section{Recommendations}

According to the findings of the present study, the researcher suggested the following recommendations:

1- Organizations system should include information and experiences opportunities about the importance of job characteristics in improving nurses' satisfaction, motivation and quality of care.

2- Continues meetings between nurse managers and nurses should be conducted to discuss their experiences, interests and views of their job.

3- Improving the payment system for nurses at Assuit University Hospitals to deal with their dissatisfaction.

4- The organization system should provide opportunities for career development for nurses in order to motivate them.

5- Establishing motivation system for work.

6- Further research about job characteristics and its' impact on nurses personal and work outcome in the remaining Assuit University Hospitals should be done.

\section{References}

18. Abu Elanain, H., (2008): Employees Perceptions of Job Characteristics in a Non-Western Context: An Examination of the Relationship between Job Characteristics and Work Attitudes and Behaviors in the UAE Refereed paper University of Dubai.

19. Alini, S., Ali, M., \& Said, N., (2014): Hackman and Oldham 's Job Characteristics Model to Job Satisfaction. Procedia - Social and Behavioral Sciences, 129, Pp. 46-52. Available online at www.sciencedirect.com.

20. Bahrami, S., Torki, S., \& Isfahani, S., (2013) : Characteristic Perception and Intrinsic Motivation in Medical Record Department Staff. Original Paper, Vol. (67), No. (1),Pp. 51-55. DOI: 10.5455/medarh.2013.67.51-55.

21. Batchelor, J., Abston, K., Lawlor, K., \& Burch, G., (2014): The Job Characteristics Model: An Extension to Entrepreneurial Motivation. Small Business Institute Journal, Vol. (10), No. (1), Pp. $1-10$.

22. Bauer, T., \& Erdogan, B., (2012): An Introduction to Organizational Behavior Chapter 5: Theories of Motivation \& Chapter 6: Designing a Motivating Work Environment. https://2012books.lardbucket.org/pdfs/anintroduction-to-organizational-behavior-v1.1.pdf

23. Behson, S., \& Eddy, E., (2000): The Importance of The Critical Psychological States in The Job Characteristics Model: A Meta-Analytic and Structural Equations Modeling Examination, Current Research In Social Psychology, Vol. (5), No. (12)

24. Campion A., (1988): Interdisciplinary approaches to job design: A constructive replication with extensions. Journal of Applied Psychology, Vol. (73), Pp. 467-481.

25. Craig. R., \& Antoinette. B., (2008): Job design for evaluation. Evaluation Capacity Development Group .http://www.ecdg.net/wpcontent/uploads/2012/04/Job-Design-PDF.pdf

26. Dobre, O., (2013): Employee motivation and organizational performance, Review of Applied Socio- Economic Research, Vol.5, No. (1), Pp. 53-60.

27. Gabr, H., \& Mohamed, N., (2012): Job characteristics model to redesign nursing care delivery system in general surgical units, Academic Research International, Vol.(2), No. (1), Pp.199-211.

28. Hackman, J., \& Oldham, G., (1975): Development of the job diagnostic survey. Journal of Applied Psychology, Vol. (60), Pp.159-170.

29. Hadi, R., \& Adil, A., (2010): Job Characteristics as Predictors of Work Motivation and Job Satisfaction of Bank Employees, Journal of the 
Indian Academy of Applied Psychology Vol. (36), No. (2), Pp. 294-299.

30. Iffat S., Jean G., \& Mohamed H., (2015): Impact of Job Characteristics on Employees Emotions \&Work-Related Outcomes in Pakistan, International Journal of Business and Management, Vol. (10), No. (8) Pp.1833-3850.

31. Kumar, A., Abbas, Q., Ghumro, I., \& Zeeshan, A., (2011): Job characteristics as predictors of job satisfaction and motivation. Asian Journal of Business and Management Sciences, Vol. (1), Pp. 206-216.

32. Leblanc, C., (2013): The Relationships Between Job Characteristics and Job Satisfaction Among Call Center Workers. Education Doctoral. Paper 199. http://fisherpub.sjfc.edu/education_etd

33. Michailidis, M., \& Dracou, N., (2011): The job redesigning process: A study of medical representatives using the job characteristics model. The Business Review, Vol. (17), No. (1), Pp. 228-234.

34. Mohamed, A., (2004): Using the job characteristics model to compare patient care assignment methods of nurses, Eastern Mediterranean Health Journal, Vol. (10), No. (3), Pp.389-405.

35. Morgeson, F., \& Humphrey, S., (2006). The Work Design Questionnaire (WDQ): Developing and validating a comprehensive measure for assessing job design and the nature of work. Journal of Applied Psychology, 91, 1321-1339.

36. Nadeem, B., Anwar A., \& Shaikh, F., (2012): Job Satisfaction and Motivation in Banking Industry in Pakistan. Journal of Asian Business Strategy, Vol. (2), No.(3), pp. 54-62.

37. Shani, N., \& Anandkumar, V., (2011): A Study on Job Characteristics and Internal Work Motivation among Icici Bank Employees, International Journal of Management ( IJM ), Vol.(2), Issue (2), pp. 56-65. 